IBIMA Publishing

Journal of Innovation \& Business Best Practice

http://www.ibimapublishing.com/journals/JIBBP/jibbp.html

Vol. 2017 (2017), Article ID 753806, 15 pages

DOI: $10.5171 / 2017.753806$

Research Article

\title{
Types of Innovation in the Czech Republic and Their Help
}

\author{
Simona Činčalová \\ University of Pardubice, Pardubice, Czech Republic \\ st30307@student.upce.cz
}

Received date: 19 September 2016; Accepted date: 9 December 2016; Published date: 25

January 2017

Academic Editor: Marta-Christina Suciu

Copyright (C 2017. Simona Činčalová. Distributed under Creative Commons CC-BY 4.0

\begin{abstract}
The role of innovation is important at all stages of development. Specifically, the creation and diffusion of technologies are important for economic growth and welfare across all economies. The aim of this article is to analyze innovation from a theoretical perspective and focus on assistance of innovation in the Czech Republic - overview of institutions supporting the innovation activities of small and medium-sized enterprises (SMEs), their characteristics and selected programs that are used to support the development of innovative activity of SMEs. Further innovations are evaluated in terms of macroeconomics, and finally, analysis of the use of various types of innovation in manufacturing industries is made. Different types of innovation play a role at various stages. Opportunities for successful innovation experiments and a potentially different framework for development are emerging. The influence of the state for competitiveness and innovation is indisputable. The state is a mediator that affects how businesses can be competitive and innovative.
\end{abstract}

Keywords: Innovation, types of innovation, manufacturing industries

\section{Introduction}

For businesses, whether large or small and medium, it is increasingly difficult to maintain their competitiveness on the basis of the prices of factors and to have to strive to produce increasingly using high share knowledge, especially innovation. The role of innovation is to maintain productive economies crucial and enable enterprises from developed countries, which have to face competition from developing economies, to succeed in globalized markets. Businesses must

Cite this Article as: Simona Činčalová (2017)," Types of Innovation in the Czech Republic and Their Help ", Journal of Innovation \& Business Best Practice, Vol. 2017 (2017), Article ID 753806, 
increasingly compete with the production of unique, specific know-how innovations; they have to transfer their activities to research and knowledgeintensive productions that require high skills and adaptability of the workforce.

The aim is to analyze innovation from a theoretical perspective and focus on supporting innovation in the Czech Republic - overview of institutions supporting the innovation activities of small and medium-sized enterprises (SMEs), their characteristics and selected programs that are used to support the development of innovative activity of SMEs. Further innovations are evaluated in terms of macroeconomics, and finally, analysis of the use of various types of innovation in manufacturing industries is made.

\section{The Theoretical Basis}

Competitiveness is a feature that allows a business to succeed in competition with other operators who seek to achieve the same or very similar goals. It is relying on internal resources and organizational arrangements that allow him to operate effectively and efficiently so that he can take advantage of changes in their surroundings as opportunities for success in the competition better and before it can do its competitors. (Pitra, 2011; Stamm, 2005)

Innovation is one of the most important factors of competitiveness. Innovations are, according to Pitra (2006), understood as a new way of using external resources of the enterprise to obtain new business opportunities, i.e. to find new ways to increase revenues from its business activities. Creating something new (the result of creativity of company) must be always focused on the customer who must be offered a higher value. Innovation may refer to products, processes, management methods and business model.
Schumpeter (1960) argues that innovation is a term which refers to the practical implementation of new solutions for product, process or organization in the company. Those new innovative products or processes have an economic value.

According to Engel (2015), the innovative leaders are in their field more successful than their competitors and can create up to four times more value for your business than the average competitors in the field.

The most common myths concerning innovation are (Hamel, 2007):

- Innovations come from big ideas,

- Innovations relate to the creation of new products,

- Innovative solutions can be learned, it is the result of creative ideas,

- Innovations are matter specialists from the departments of research and development,

- Innovation is risky,

- Innovations are costly,

- The success of innovation activities is proportional to the volume of investment in research and development,

- Innovation is the result of the interplay of favorable conditions.

Bessant and Tidd (2015) proposed the "4P Model", which assumes that successful innovation is essentially a positive change. Model 4P is composed of four categories, where such change comes from (see Figure 1).

Product innovation refers to changes in the goods or services it offers. Process innovation is changing the way products and services are developed and delivered. Marketing innovations (position) brings changes in the context in which those products or services are placed on the market. Organizational innovation (innovation paradigm) means a change in 
basic mental models that shape beyond what the company is doing.

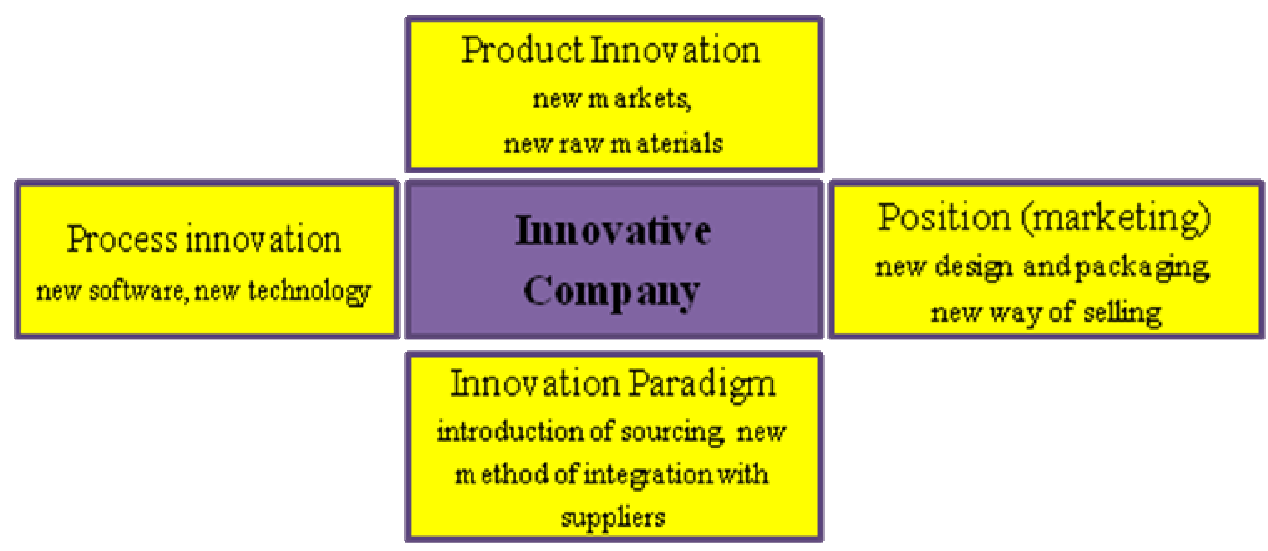

Fig. 1: Model of main types of innovation.

Source: own processing

\section{Support for Innovation}

In the Czech Republic, innovations are supported by governmental and nongovernmental institutions. Overview of institutions is reported in Table 1. The specific measures of state economic policy are set out in section 2.3.

Table 1: Institutions supporting innovation in the Czech Republic

\begin{tabular}{|c|c|}
\hline Government institutions & Non-governmental institutions \\
\hline $\begin{array}{l}\text { - Grant Agency of the CR } \\
\text { - Technology Agency of the } \\
\text { CR } \\
\text { - The Ministry of Industry and } \\
\text { Trade CR } \\
\text { - Business Development } \\
\text { Agency CzechInvest }\end{array}$ & $\begin{array}{l}\text { - } \text { Association of Innovative } \\
\text { Entrepreneurship } \\
\text { - } \text { CzechInno } \\
\text { - } \text { Technology Centre AV CR } \\
\text { - Science and Technology Parks CR } \\
\text { - Chamber of Commerce CR } \\
\text { - Centre for Knowledge and Technology } \\
\text { Transfer }\end{array}$ \\
\hline
\end{tabular}

Source: own processing 
Government organization supporting innovation in the Czech Republic

Grant Agency of the Czech Republic (GACR) is an independent state institution that supports basic scientific research in the country. As part of the announced programs GACR supports research projects for both researchers and teams, as well as small and young scientists. Also funded bilateral projects and projects solved within the framework of European and international programs. Annually approximately 3,000 petitioners are applying for GACR grants, while roughly one quarter of the grant was obtained.

Technology Agency of the Czech Republic (TACR) is a state organization, which was established in 2009 by the state on support of research, experimental development and innovation. TACR centralizes state support applied research and development, which had previously been scattered among a large number of providers.

The Ministry of Industry and Trade of the CR is the bearer of the Operational Programme Enterprise and Innovation. The program aims to increase the innovation potential of the business sector through subsidies for the implementation of innovation among enterprises (especially SMEs) and projects of public research institutions, universities, individuals and SMEs aimed at protecting industrial property rights.

Business Development Agency CzechInvest is an organization that is subordinate to the Ministry of Industry and Trade and strengthens the competitiveness of the Czech economy through SME support, business infrastructure, innovation and attracting foreign investment in the manufacturing, strategic services and technology centers.

\section{Non-governmental organization promoting innovation in the Czech Republic}

Association of innovative entrepreneurship are interested in the field of innovative entrepreneurship, i.e. research, development and innovation, technology transfer, new materials and technologies, technology parks, innovative companies, innovative processes, innovation infrastructure, innovation potential and conditions for a functional innovative market, while respecting the rules of the Community framework of the EU and other generally binding regulations.

CzechInno is an association of people interested in innovation, which focuses on all-round development and support of innovative processes in companies and provides information on science, research and innovation, and their associated services. Candidates are grouped around the same web portal.

Technology Centre AV CR (TCAV) is a nonprofit association of legal entities. Members of the association are run by the Academy of Sciences. TCAV is a major national center for research and innovation infrastructure and performs oriented research in the fields of science, technology and innovation. It is the source of current information on European research, development and innovation.

Science and Technology Parks CR is an association of science and technology parks that have, or are prepared in an environment of scientific and research institutions and in the university environment. Formed on the initiative of production, trade and other business entities in the border areas, on the initiative of private individuals, they become part of regional development plans. 
Chamber of Commerce CR serves to support entrepreneurial activities to promote and protect the interests of its members. Within its scope, it primarily provides advisory and consulting services on issues related to business activity, organizes educational activities and provides information about professional education and forms of retraining, establishes and develops contacts with chambers of commerce, professional institutions abroad and concludes agreements with them, issues certificates arising legal relations in international trade, carries out its own economic activity to support the proper performance of their tasks.

The Center for Knowledge and Technology Transfer (CKTT) is a part of Charles University (UK), providing services and information to support the transfer of knowledge and technologies that create opportunities and environments for their propagation to increase the competitiveness of the UK and attractiveness to students, employees, but and the public. CKTT is building its own innovation network, within which are connected UK academics, but also innovative organizations outside the UK. The same principle works in institution in Pardubice called University Centre of technology transfer and knowledge (CTTK), which works with businesses and students from April 2012.

\section{Measures of State Economic Policy}

The economic policy of the state is also related to the support of innovation. The economic policy is defined as the sum of the objectives, instruments, decisionmaking processes and state measures aimed at controlling and influencing economic development. The objectives of economic policy include: economic growth, GDP growth, high employment, price level stability and balanced foreign trade balance.

One of the instruments of economic policy is out of fiscal, monetary and income policies also external trade and monetary policy. The state is trying to regulate imports of goods and services, to promote exports and to regulate uses tools:

- determination of import and export quotas - determine the maximum amount of goods that can be for a period of time to import into the country,

- tariff policy - the bearer's government,

- preferential lending to exporters,

- Regulation of exchange rates - the effect on flows of goods and services to the ebb and flow of capital. (Mach, 2001)

Especially in democratic countries, efforts have been made on the elimination of borders and barriers, not only the geographical, but also the economic ones, which facilitates innovative activity in the countries. In this context, you can use the expression liberalization of international trade or release. According to Štěrbová (2013), the liberal approach is leading, inter alia, to increase competition in the domestic market. Competitiveness will therefore undoubtedly work in liberal market.

Currently, the liberalization is the goal of many countries including the EU. EUexpects liberalization in their strategies and visions of future, treats it as a positive phenomenon and it confirms the membership in the World Trade Organization (WTO), for example, but also by a Transatlantic trade and investment partnership (TTIP).

TTIP is according to Villea and SilesBrüggea (2016) free-trade agreement between the EU and the US and is 
expected to be the most important bilateral trade deal ever. Negotiations were launched in July 2013 and by the assumptions and preliminary analyzes by closing TTIP could have to raise EU GDP by $0.5 \%$ (in US GDP by $0.4 \%$ ) until 2027 . EU exports to the US, according to European Commission estimates, a study of the Centre for Economic Policy Research was thanks to an agreement to increase by $28 \%$. In some sectors, it could be a significant increase for the Czech Republic - for example, exports of cars from the EU to the US could increase by up to $149 \%$. (Francois, 2013)

Liberal policy in foreign trade also brings a wide range of threats (e.g. a voluntary waiver of certain options to restrict the entry of goods into the internal market, allowing uncontrolled exports of goods uncontrollable prices). The EU, however, absolutely does not give options to intervene and affect such import goods which liquidates or which would have threatened destruction of an industry in the EU. One of the tools used in this context is the concept of anti-dumping duties. Anti-dumping duty is a legitimate means for certain restrictions on the harmfulness of certain imports, which it damages ome EU industry.

For example, in 2006 the European Commission found that the governments of China and Vietnam conducted interventions in the sector of leather industry by providing tax holidays, nonmarket land lease, improper valuation of assets and others. Such state intervention leads to dumping, which is according to the rules of the WTO incompatible. EU Trade Commissioner Mandelson proposed to impose on those imports first temporary duty (for 5 months) and a few months later pushed through the adoption of anti-dumping duties on imports of leather shoes from China and Vietnam at the level $16.5 \%$. These duties should be effective for a period of 2 years. (Fojtíková, Lebiedzik, 2008)

\section{Evaluation of Innovation Activity from A Macroeconomic Perspective}

Nezval and Majerová (2013) argue that innovation cannot be understood only as the introduction of new products and production processes, as well as the applying changes in work organization and management, or new ways of selling products. Innovation performance is not only related to the ability of enterprises, but is also bound to the environment of the entire national system, including a system of public and private institutions. Their activities and links ensure the creation, transmission and application of new knowledge and its consistency and continual interactions are important for the functioning of the national innovation system.

Researchers and innovators must be able to work freely throughout the EU. They should remove the last obstacles for entrepreneurs to be able to quickly bring to market their ideas. Innovation activities also represent a potential for increasing employment. They should not be involved only large companies but also SMEs, not only in the production sector, but also in the public sector and social services. But how is such innovative activity, respectively performance of the country, measured?

\section{Innovation performance - Summary Innovation Index}

Innovation performance captures and measures the number of international institutions. At the level of European economies Summary Innovation Index (SII) is drawn, and at the global level there are two Global Innovation Index (GII), each of them is compiled by another organization. Other text will deal only with SII, which is the oldest of these indices.

SII is the main instrument for mutual comparison of the innovation 
environment and innovation performance of national economies in Europe, which is compiled since 2001. It belongs to the aggregate indicators that summarize the data of two or more individual indicators (indicators of innovation, science and research) and allow the multidimensional nature of innovation performance. (Nezval, Majerova, 2013)
SII distinguishes three main types of indicators - enablers (assumptions), firm activities and outputs - they are spread over 8 innovation dimensions and a total of 25 indicators (see a graphic in Figure 2).

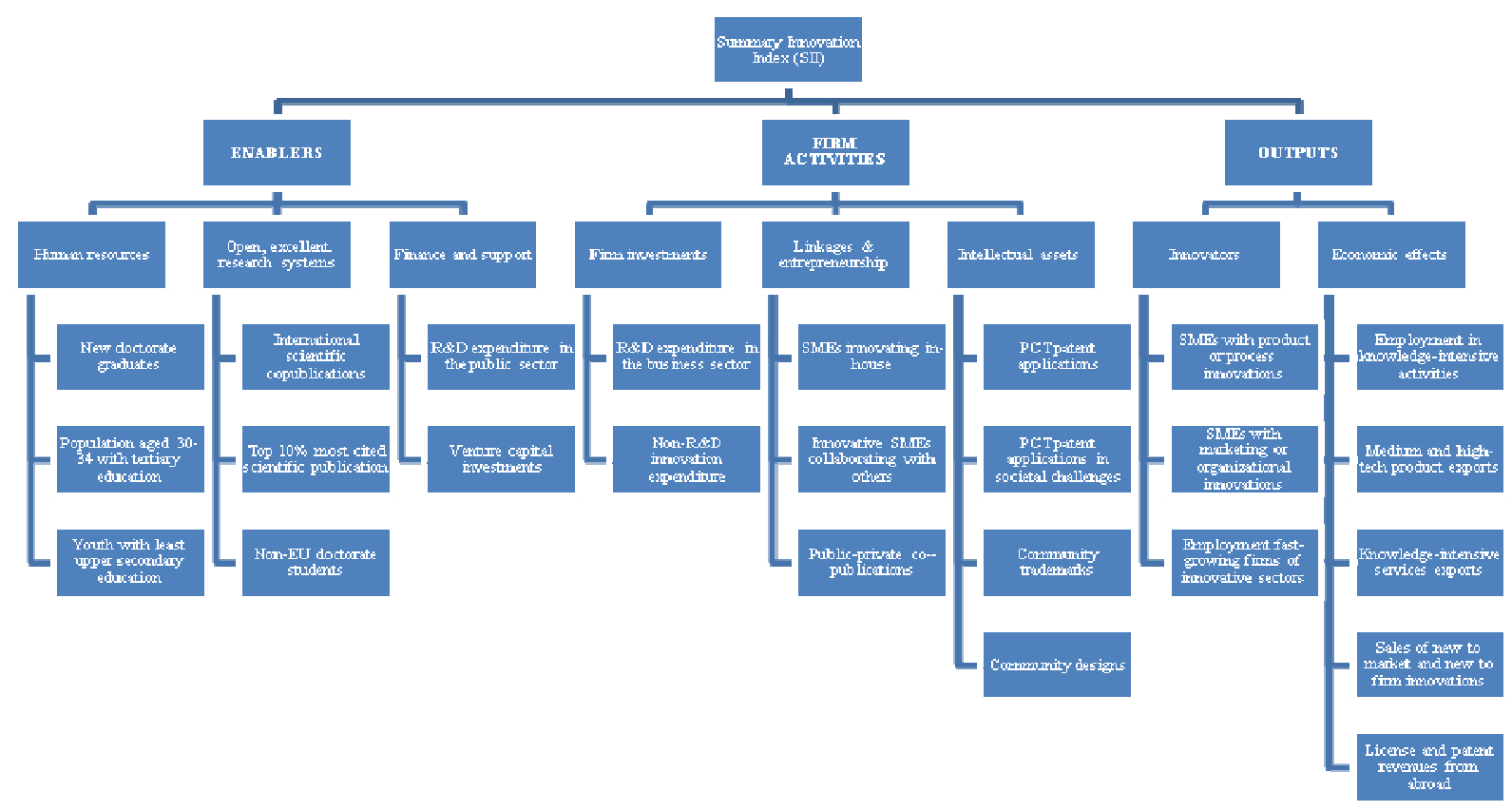

Fig 2: Indicators Summary Innovation Index

Source: own processing according to Hollanders et al. (2015)

The enablers include, for example, new graduates of doctoral studies and investment in venture capital. Business activities are evaluated by investments in research and development, or patent applications of PCT (Patent Cooperation Treaty). Finally, outputs monitor innovation in small and medium-sized enterprises, or for example, income from licenses and patents abroad.

Evaluation of research and innovation performance of EU member states (and selected countries outside the $\mathrm{EU}$ ) is performed annually in the form of an evaluation report of the Innovation Union for the year (see Figure 3). 


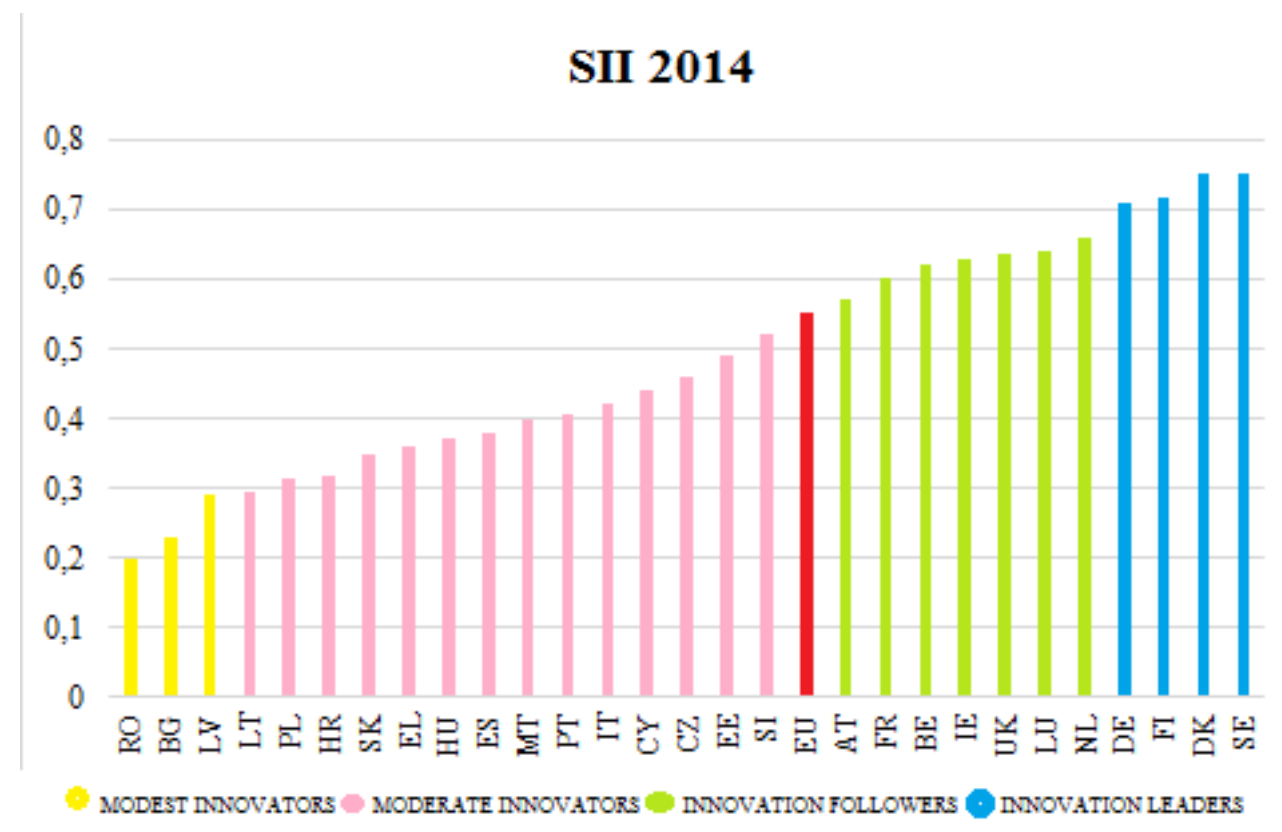

Fig 3: Innovation performance in the EU - SII 2014

Source: own processing according to Hollanders et al. (2015)

Based on the innovative performance, the selected countries are divided into four groups:

- innovation leaders - the innovation performance of countries with this status is significantly higher than the EU average,

- innovation followers - innovative performance in these countries is above the EU average,

- moderate innovators - the innovative power of this group is slightly below the EU average,

- modest innovators - these countries have innovation performance well below the EU average.

The evaluation report of the Innovation Union is also taking an amount of other information such as a country with significant dynamics within the partial evaluation criteria, the areas in which the EU has improved or deteriorated as a whole (because the evaluation includes strong economies such as the US, Japan China, Russia).
The Czech Republic is in the context of innovation performance in recent years ranked among the "moderate innovators", although within this group gradually shifts to a higher place. Innovation leaders are Sweden, Denmark, Finland and Germany, and vice versa in the most innovative performance lagging behind Romania, Bulgaria and Latvia.

Development of the Czech Republic in comparison with the European Union is shown in Figure 4. As already mentioned, and you can see from the chart, the Czech Republic several years is slightly below the EU average. 


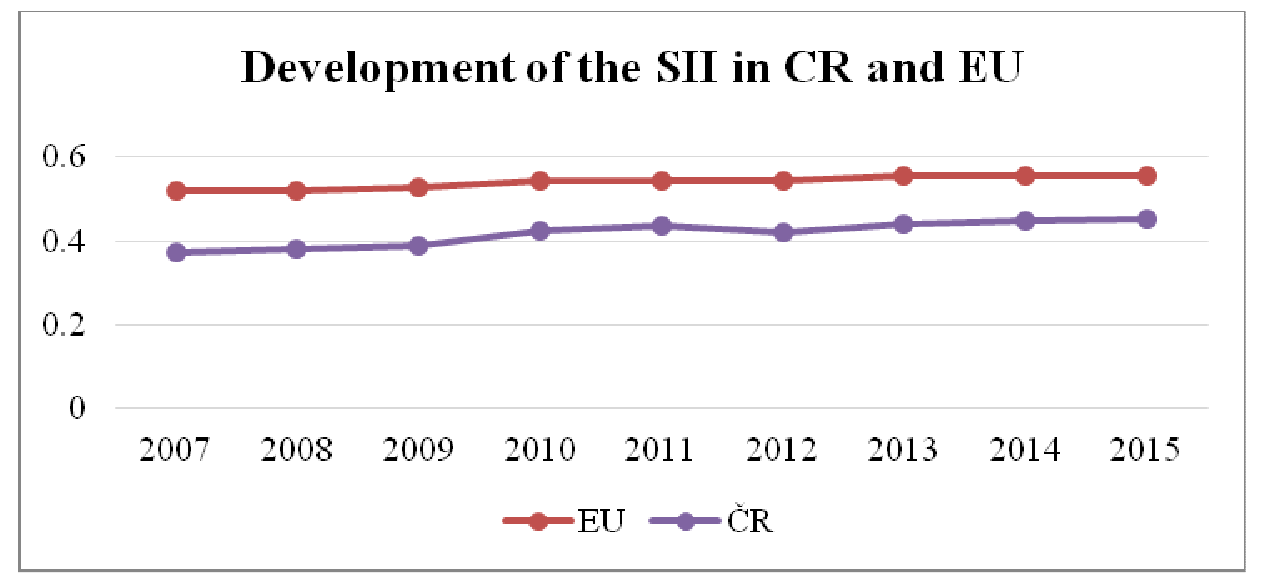

Fig 4: Development of the Summary Innovation Index CR and EU

Source: own processing

In 2015, the CR positively affected most indicators, Recent PhD graduates, Innovative SMEs collaborating with others and employment in the rapidly growing sector of innovative enterprises. Conversely, a negative impact on innovation performance indicators $\mathrm{CR}$ had cooperation between the public and private sector publications SMEs with marketing or organizational innovations and the sale of new innovations for the company and for the market.

\section{Strategy Europe 2020}

Europe 2020 is the EU's ten-year strategy, which was launched in 2010. Its aim is to achieve economic growth and more employment. Its task is not only to overcome the crisis but also to solve the shortcomings of the current model of economic growth and create the conditions for smart, sustainable and inclusive growth.

For this purpose, the Strategy sets out five main objectives that the EU must achieve by 2020 (Eurostat, 2016):
- employment - $75 \%$ of people in the age group 20-64 years,

- research and development - an investment of $3 \%$ of EU GDP,

- climate change and sustainable energy sources - to reduce greenhouse gas emissions by $20 \%$, increase the share of renewables to $20 \%$ and energy efficiency by $20 \%$,

- education - to reduce dropout degree below $10 \%$, at least $40 \%$ of university-educated population in the age group 30-34 years,

- fight against poverty and social exclusion - to reduce by at least 20 million the number of people living in poverty and social exclusion or are at risk of poverty and risk of social exclusion.

How does the Czech Republic currently stand (compared with the Europe 2020 objectives) can be seen in the following Table 2 . It is gradually managing to fulfill these goals, but the biggest problem so far seems to be reducing greenhouse gas emissions. 


\section{Table 2: Comparison of current values of the Czech Republic and Europe 2020 goals}

\begin{tabular}{|c|c|c|}
\hline Targets & CR 2015 & Europe 2020 \\
\hline Employment & $75-77 \%$ & $75 \%$ \\
\hline Research and development investments & $1,5 \%$ GDP & $3 \%$ GDP \\
\hline Greenhouse gases & $+9 \%$ & $-20 \%$ \\
\hline The share of renewable sources & $+13 \%$ & $+20 \%$ \\
\hline Energy efficiency & $+39,6 \%$ & $+20 \%$ \\
\hline Level of uncompleted studies & $5,5 \%$ & $<10 \%$ \\
\hline University educated population 30-34 years & $32 \%$ & $40 \%$ \\
\hline $\begin{array}{l}\text { The number of people living in poverty } \\
\text { or social exclusion }\end{array}$ & -30000 & -20000000 \\
\hline
\end{tabular}

\section{Innovation Union}

The already mentioned document of the European Commission's Innovation Union is a part of the Europe 2020 strategy document and sets a goal to increase spending on research and development to 3\% of GDP (now it is about $1.5 \%$ ). To this target, it proposes 34 measures to ensure access to innovation with support at the highest political level (eg. to strengthen the knowledge base, bringing new ideas to market, European Innovation Partnership). The measures are divided into six areas, as shown in Figure 5.

\begin{tabular}{|c|c|}
\hline \multicolumn{2}{|c|}{ Strengthening the knowledge base } \\
\hline Bringing new ideas to market & Maximization of social and territorial cohesion \\
\hline European innovation partnership & Disseminationg our goals \\
\hline \multicolumn{2}{|c|}{ Implementing the Innovation Union } \\
\hline
\end{tabular}

Fig 5: Measure Innovation Union - 6 key areas

Source: own processing according to Metodika ř́zení inovací a jejich implementace pro MSP (2015)

This is a desire to use public sector intervention to stimulate the private sector and by removing obstacles which stop ideas reaching the market, such as lack of finance, fragmented research systems and markets, inadequate public procurement for innovation and slow standard setting.

Fulfilling the objective of increasing investment in research and development to 3 percent of GDP could create 3.7 million jobs (till 2025) and annual GDP could grow by 795 bn. Euros. This will require a million more researchers.

\section{Analysis of the Use of Various Types of Innovation in Specific Sectors}

The types of innovations - model 4P were briefly described in the first chapter. These types distinguish the product, process, organizational and marketing innovation. In the following, we will discuss in which sectors of the manufacturing industry (CZ-NACE C) that type of innovation can be applied because not every type is suited for every industry.

Based on the research literature and CSO statistics, we came to the following conclusions (see Table 3). Product innovation, which refers to the 
introduction of new or significantly improved goods and services (e.g. technical parameters), is the most attractive in the petrochemical and chemical industry, where this innovation was introduced in 2012-2014 (the time span applies to all other data) $605 \%$ of companies in the sector. At least companies that have implemented product innovation have been in the wood and paper industries (only $20.7 \%$ of enterprises).

Process innovation or the introduction of new or significantly improved production or supply methods (eg. equipment) was again the most foothold in the petrochemical and chemical industry (47.4\% of enterprises in the sector). At least it appears appropriate to the sector of textile, clothing, leather and footwear industry (innovated only $16.8 \%$ of enterprises).
Marketing innovation, entailing the introduction of a new marketing method, which includes significant changes in product design or packaging, product placement, promotion or its award most often was introduced in the petrochemical and chemical industry (43.9\% of enterprises) and the least in the automotive industry (only 16\% of enterprises).

Organizational innovation, which is defined as the introduction of a new organizational method in the firm's business practices, in workplace organization or external relations, is used the most in the manufacture of other transport equipment $\quad(40.2 \%$ of enterprises). In all other sectors, this type of innovation introduced less than a third of the companies in the group. The least attractive sectors appear to textile, clothing, leather and footwear industry (only $\quad 13 \% \quad$ of $\quad$ companies).

\section{Table 3: Attractiveness of the industry for different types of innovation}

\begin{tabular}{|c|c|c|}
\hline Type of innovation & Attractive sector for innovation & Unattractive sector for innovation \\
\hline Product innovation & $\begin{array}{l}\text { - petrochemical and } \\
\text { chemical industry } \\
\text { manufacture of other } \\
\text { transport equipment }\end{array}$ & $\begin{array}{l}\text { - } \quad \text { woodworking, paper industry } \\
\text { manufacture of basic metals } \\
\text { and fabricated metal products }\end{array}$ \\
\hline Process innovation & 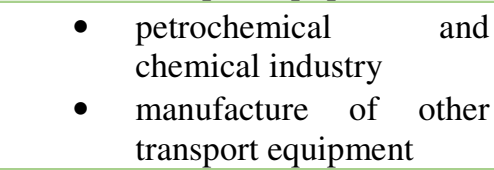 & $\begin{array}{l}\text { - } \quad \text { textile, clothing, leather } \\
\text { and footwear industry } \\
\text { - } \quad \text { manufacture of furniture }\end{array}$ \\
\hline $\begin{array}{l}\text { Marketing } \\
\text { innovation }\end{array}$ & 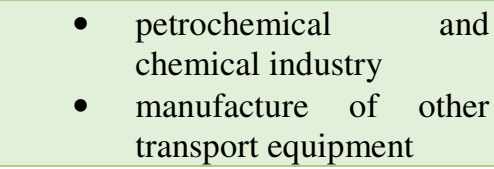 & $\begin{array}{ll}\text { - } & \text { automotive industry } \\
\text { - } & \text { manufacture of furniture }\end{array}$ \\
\hline $\begin{array}{l}\text { Organisational } \\
\text { innovation }\end{array}$ & $\begin{array}{l}\text { - manufacture of other } \\
\text { transport equipment } \\
\text { petrochemical and } \\
\text { chemical industry }\end{array}$ & $\begin{array}{l}\text { - textile, clothing, leather } \\
\text { and footwear industry } \\
\text { food, drink and tobacco } \\
\text { industry }\end{array}$ \\
\hline
\end{tabular}

Source: own processing

Because the table is free from some manufacturing industries and some are often repeated, we decided to put another one in which we carried the appropriate types of innovations for specific sectors (see Table 4). As you can see, not every 
type of innovation is suitable for each sector. Nevertheless, one can find such a sector in which you can apply all kinds of innovation - the petrochemical and chemical industries, and the manufacture of other transport equipment.

\section{Table 4: Suitability for Introducing Innovations in Each Sector}

Manufacturing industries

Food, drink and tobacco industry

Textile, clothing, leather and footwear industry

Wood and paper industry

Petrochemical and chemical industry

Pharmaceutical industry

Rubber and plastics industry

Glass, ceramics, porcelain and building materials

Manufacturing of basic metals and fabricated metal products

Manufacture of computer, electronic and optical equipment

Manufacture of electrical equipment

Engineering industry - manufacturing machinery

Automotive industry

Manufacture of other transport

Furniture production; Other manufacturing

Source: own processing

In the above text, it was noted that product innovation can be either new to the market, or only for new business. We will focus on whether there is a relationship between the number of innovations and sales, or that such innovation has a greater effect on sales, in
Suitable type of innovation product, process, marketing product, marketing organizational product, process, marketing, organizational product, marketing product, process product, process, marketing process product, process product, process product, process product, process, organizational product, process, marketing, organizational product

other words, which of these innovations has a stronger correlation relationship with the revenues from the given innovation. Input data from the years 2012-2014, with which we will continue to work, come from the CSO (see Table 5). 
Table 5: Number of Innovations and Revenues According To Their Novelty

\begin{tabular}{|c|c|c|c|c|}
\hline \multirow[b]{2}{*}{ Manufacturing industries } & \multicolumn{2}{|c|}{ New for the market } & \multicolumn{2}{|c|}{ New just for business } \\
\hline & $\begin{array}{l}\text { Number of } \\
\text { nnovations }\end{array}$ & Sales & $\begin{array}{l}\text { Number of } \\
\text { innovations }\end{array}$ & Sales \\
\hline Food, drink and tobacco industry & 190 & 10868 & 323 & 19743 \\
\hline Textile, clothing, leather and footwear & 75 & 4888 & 126 & 7718 \\
\hline Wood and paper products & 106 & 1876 & 215 & 10055 \\
\hline Petrochemical and chemical industry & 84 & 5343 & 118 & 7269 \\
\hline Pharmaceutical industry & 12 & 1088 & 18 & 2301 \\
\hline Rubber and plastic industry & 156 & 22883 & 233 & 27360 \\
\hline Glass, ceramics, porcelain and building materials & 136 & 9358 & 128 & 9834 \\
\hline $\begin{array}{l}\text { Manufacturing of basic metals and fabricated metal } \\
\text { products }\end{array}$ & 321 & 36011 & 380 & 45623 \\
\hline Production of computers, el. and optical equipment & 85 & 62804 & 111 & 12069 \\
\hline Manufacture of electrical equipment & 134 & 12792 & 191 & 38519 \\
\hline $\begin{array}{l}\text { Engineering industry - manufacturing machinery / } \\
\text { equipment }\end{array}$ & 278 & 29751 & 326 & 42512 \\
\hline Automotive industry & 89 & 255388 & 117 & 139379 \\
\hline Manufacture of other transport equipment & 39 & 8026 & 44 & 8264 \\
\hline Furniture production; Other manufacturing & 159 & 5728 & 218 & 6947 \\
\hline
\end{tabular}

Source: own processing according to the Czech Statistical Office (2016)

For calculating the correlation dependencies, we will use function CORREL in Excel. Until then, we only need to enter two areas with data in which we identify interdependencies. The result is a correlation (see Table 6).

Table 6: Results of correlation coefficients

\begin{tabular}{|l|l|}
\hline Products new for the market & \multicolumn{1}{c}{$\begin{array}{l}\text { Correlation } \\
\text { coefficient }\end{array}$} \\
\hline Products new for business & $-0,044092755$ \\
\hline
\end{tabular}

Source: own processing

The correlation coefficient can take values from -1 to 1 . When the correlation coefficient is close to -1 , it means that the dependency is strong but indirect. The higher one factor, the lower the second one. If the correlation coefficient is around 0 , it means that there is almost no dependency. And if the correlation coefficient approaches 1 , it means that the dependency is strong and direct, i.e. the higher one factor, the higher the second one.
In our case, the correlation coefficient is for new products on the market 0.044092755 and new products for enterprise 0.148876793 . What does it mean? Products that are new only to the enterprise increase its revenues more than the products new to the market. However, when considering whether the dependency between variables exists or not, we have to recognize whether we have enough data. This can be determined by the table of critical values. 
If we work with 95\% probability and we have 14 values, according to the tables of critical values, we need correlation coefficient at minimum level 0.5324 . So we can't be $95 \%$ sure whether the new products on the market / enterprise affect the sales positively or negatively. It was therefore found to addiction and cannot be said that the more product innovations (new to the company or the market), the better.

\section{Conclusions}

In the first part of this work, we analyzed theoretical approaches to innovation and individual types of innovations. The definition of innovation is diverse, and there are also different types of innovation. Innovation is a process that must increase the value of the product or service as a result of positive changes, it must be significantly different. As a result, productivity is a fundamental source of wealth for the growth of economies.

The second chapter is dedicated to the institutions that support innovation in the Czech Republic. Other parts are aimed at measuring innovation activities, compared to the Czech Republic with the European Union and Europe 2020 Strategy. Finally, we analyzed the use of various types of innovation in manufacturing industries. The goals of the articles were thus fulfilled.

The influence of the state and the macroeconomic environment for competitiveness and innovation is undeniable. The state is a mediator that affects how businesses can be competitive and innovative.

The Czech Republic lags behind in innovation activities. The question is: what to change in the approach to these innovative activities in the business environment so as to achieve better economic performance of the Czech Republic? This topic is needs, therefore, further research, which will deal with innovations in greater depth.

\section{References}

BÉNASSY-QUÉRÉ, A. Economic policy: theory and practice. Oxford: Oxford University Press, 2010. ISBN 978-0-19532273-6.

BESSANT, J. R., TIDD, J. Innovation and entrepreneurship. Third Edition. Hoboken, New Jersey: Wiley, 2015. ISBN 9781118993095.

ENGEL, K. Masters of innovation: building the perpetually innovative company. London: LID, 2015. ISBN 1907794964.

Eurostat: Your key to European statistics [online]. Lucemburk, 2016 [cit. 2016-07-07]. Available: http://ec.europa.eu/eurostat

FOJTÍKOVÁ, L., LEBIEDZIK, M. Společné politiky EU: historie a současnost se zaměřením na Českou republiku. Praha: C.H. Beck, 2008. Beckova edice ekonomie. ISBN 978-80-7179-939-9.

FRANCOIS, Joseph. Reducing Transatlantic Barriers to Trade and Investment: An Economic Assessment [online]. London: Centre for Economic Policy Research, 2013, 124 [cit. 2016-07-04]. Available: http://trade.ec.europa.eu/doclib/docs/2 013/march/tradoc_150737.pdf

HAMEL, G. The future of management. Boston, Mass.: Harvard Business School Press, c2007. ISBN 1422102505.

HOLLANDERS, H., ES-SADKI, N., KANERVA, M. Innovation Union Scoreboard 2015 [online]. Maastricht Economic and Social Research Institute on Innovation and Technology. Belgium: European Union, 2015 [cit. 2016-06-06]. ISBN 978-92-79-44089-2. Available: http://ec.europa.eu/growth/industry/in novation/facts- 
figures/scoreboards/files/ius2015_en.pdf

MACH, Miloš. Makroekonomie II: pro magisterské (inženýrské) studium. Vyd. 3. Slaný: Melandrium, 2001. ISBN 80-8617518-9.

Metodika řízení inovací a jejich implementace pro MSP: Metodická př́ručka č. 3. In: Slezská univerzita $v$ Opavě: Obchodně podnikatelská fakulta v Karviné [online]. Karviná: Institut interdisciplinárního výzkumu, 2015 [cit. 2016-06-08]. Available: http://www.iivopf.cz/images/Pdf_soubor y/Metodick\%C3\%A1_p\%C5\%99\%C3\%A Dru\%C4\%8Dka_\%C4\%8D.3.pdf

NEZVAL, P., MAJEROVÁ, I. Rovnováha ekonomiky, zahraniční obchod a konkurenceschopnost vybraných zemí evropského hospodárského prostoru. Karviná: SU OPF, 2013. ISBN 978-807248-902-2.
PITRA, Z. Management inovačních aktivit: Zbyněk Pitra. 1. vyd. Praha: Professional Publishing, 2006. ISBN 80-86946-10-X.

PITRA, Z. Konkurenční strategie organizací: umění vítězit $\mathrm{v}$ globální konkurenční soutěži počátku 21. století. 1. vyd. Praha: Velryba, 2011. Podnikání a management. ISBN 978-80-85860-21-4.

SCHUMPETER, J., 1960. Teoria wzrostu gospodarczego. Warszawa: PWN.

STAMM, von B. Managing innovation, design and creativity. New York: J. Wiley, c2005. ISBN 0470847085.

ŠTĚRBOVÁ, Ludmila. Mezinárodní obchod ve světové krizi 21. století. Praha: Grada, 2013. Expert (Grada). ISBN 978-80-2474694-4.

VILLE, F., SILES-BRÜGGE, G. T.T.I.P.: the truth about the transatlantic trade and investment partnership. Malden, MA: Polity Press, 2016. ISBN 9781509501021. 